\title{
Enantioselective Hydrosilylation and Hydrogenation of Alkaloid Precursors ${ }^{1)}$
}

\author{
Henri Brunner", Alfred Kürzinger, Siavosh Mahboobi, and \\ Wolfgang Wiegrebe ${ }^{* * *}$ )
}

Faculty of Chemistry and Pharmacy, University of Regensburg, Universitätsstr. 31, D-8400 Regensburg, F.R.G.

Eingegangen am 3. Juni 1987

\begin{abstract}
Enantioselective hydrosilylations of the 3,4-dihydropyrrole derivatives la-c and 5 with in-situ catalysts consisting of $\left[\mathrm{Rh}(\mathrm{cod}) \mathrm{Cl}{ }_{2}\right.$ and optically active phosphines yield the $N$-silyl compounds 2 a-c and 6 in up to $66.1 \%$ ee. The $N$-silyl derivatives were treated with acetic formic anhydride or trifluoroacetic anhydride to give the $N$-formyl and $N$-trifluoroacetyl compounds 3a-c, $\mathbf{4 a - c , 7}$, and $\mathbf{8}$. The alkaloids nicotine and macrostomine were synthesized with 63.3 and $33 \%$ ee by reduction of the $N$-formyl compounds 8 and 12. Enantioselective hydrogenations of the $N$-formyl and $N$-trifluoroacetyl-2-phenylpyrrolines 14 and 15 with the same in-situ catalysts produce the cyclic amides $3 \mathbf{a}$ and $\mathbf{4 a}$ in up to $36.1 \%$ ee.
\end{abstract}

\section{Enantioselektive Hydrosilylierung und Hydrierung von Alkaloid-} vorläufern ${ }^{1)}$

Die enantioselektive Hydrosilylierung der 3,4-Dihydropyrrol-Derivate 1a-c, 5 mit in-situ-Katalysatoren bestehend aus $[\mathrm{Rh}(\operatorname{cod}) \mathrm{Cl}]_{2}$ und optisch aktiven Phosphinen ergab die N-Silylverbindungen $2 \mathbf{2 a - c ,} 6$ in bis $\mathrm{zu}$ $66.1 \%$ ee. Die N-Silyl-Derivate wurden mit Acetylformylanhydrid bzw. Trifluoracetanhydrid versetzt, wobei die N-Formyl- und N-Trifluoracetyl-Verbindungen 3a-c, 4a-c, 7 und 8 gebildet wurden. Die Alkaloide Nicotin und Macrostomin wurden mit 63.3 und $33 \%$ ee durch Reduktion der N-Formyl-Verbindungen 8 und 12 synthetisiert. Die enantioselektive Hydrierung der N-Formyl- und N-Trifluoracetyl-2-phenylpyrroline 14 und $\mathbf{1 5}$ mit denselben in-situ-Katalysatoren ergab die cyclischen Amide 3a, 4 a mit bis zu $36.1 \%$ ee.
In the enantioselective catalytic synthesis of optically active alkaloids starting from prochiral precursors, the methods hydrosilylation and hydrogenation have been used successfully ${ }^{2-4}$ ). For the enantioselective hydrosilylation of prochiral 3,4-dihydro- $2 \mathrm{H}$-pyrrole derivatives we have obtained chemical yields of more than $80 \%$ with optical inductions of up to $64 \%$ ee $^{3)}$.

In a continuation of our efforts we describe the hydrosilylation of other 3,4-dihydro-2H-pyrrole derivatives and the hydrogenation of $\mathrm{N}$-acyl-2-phenylpyrrolines with the aim to develop enantioselective syntheses of the pyrrolidine alkaloids nicotine and macrostomine ${ }^{5,6}$. We approached this goal by using a new work-up of the $\mathrm{N}$-silyl compounds with acetic formic anhydride which allows the introduction of a $\mathrm{N}$-formyl group and its reduction to the $\mathrm{N}$-methyl group typical for nicotine and macrostomine. By this reaction sequence, cyclic five-membered imines can be converted into the alkaloids nicotine and macrostomine.

The catalytic hydrosilylation of the cyclic imines 1a-1c with diphenylsilane, which gave the silylamines $\mathbf{2 a - c}$, is shown in Scheme 1. Generally the N-Si-derivatives were not isolated but processed directly.

After derivatization with trifluoroacetic anhydride the optical purity of $4 a-4 c$ was measured by GC on a $50 \mathrm{~m}$ Chirasil-L-Val column. The configuration was assigned on the basis of the assumption that the R-enantiomer is eluted prior to the S-enantiomer? ${ }^{7}$.

The imine 1a was hydrosilylated with in-situ catalysts derived from $[\mathrm{Rh}(\operatorname{cod}) \mathrm{Cl}]_{2}$, cod $=1,5$-cyclooctadiene, and different chiral phosphine ligands. In the hydrosilylation of $\mathbf{1 a}$ with $[\mathrm{Rh}(\mathrm{cod}) \mathrm{Cl}]_{2} /(-)$-Diop in toluene $\mathbf{4 a}$ was obtained in

\footnotetext{
${ }^{* *}$ Herrn Prof. Dr. B. Witkop, NIH, USA, zum 70. Geburtstag gewidmet.
}

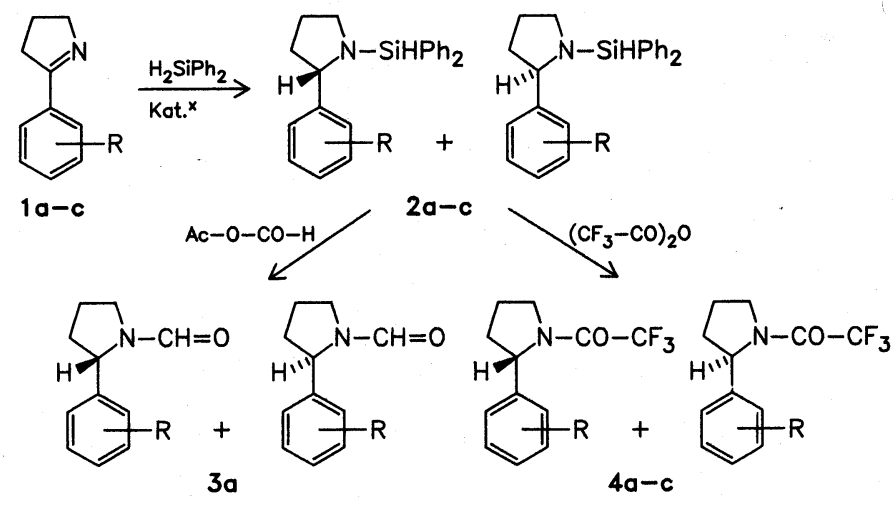

$a: R=H, b: R=m-C_{3}, c: R=p-C_{3}$

$64 \%$ ee $(\mathrm{R})^{3)}$. In $\mathrm{CH}_{2} \mathrm{Cl}_{2}$ and $\mathrm{CHCl}_{3}$ the optical induction decreased to about $40 \%$ ee with chemical yields close to $90 \%$ (Table 1). The catalysts containing (R)-(+)-Prophos, (S) (R)-(+)-BPPFA and (R,R)-(-)-Norphos gave lower optical inductions than the catalysts containing (R,R)-(-)-Diop. The in-situ catalyst $\left[\mathrm{Rh}(\mathrm{cod}) \mathrm{Cl}_{2} /(-)\right.$-Diop converted the substrates $1 \mathbf{b}$ and $1 \mathbf{c}$ into the products $4 \mathbf{b}$ and $4 \mathbf{c}$ with optical purities of $37.2 \%$ ee (R) and $49.6 \%$ ee (R), respectively (Table 1).

In addition to trifluoroacetic anhydride, acetic formic anhydride was introduced for work-up. In this derivatization, $\mathrm{N}$-formyl compounds are obtained. For $\mathbf{3 a}$ it was shown that this change does not influence the chemical and the optical yield. An advantage of the use of acetic formic anhydride for work-up is the fact that $\mathrm{N}$-formyl groups can be easily reduced to methyl groups ${ }^{8)}$. Therefore, the alkaloids nicotine and macrostomine are accessible from 8 and 12. As the formyl 
Table 1. Hydrosilylation of $2 \mathrm{mmol}$ of imines $1 \mathrm{a}-\mathrm{c}, 5,10 \mathrm{in} 2 \mathrm{ml}$ toluene with $5 \mathrm{mmol}(0.9 \mathrm{ml})$ of diphenylsilane and the in-situ catalysts $[\mathrm{Rh}(\mathrm{cod}) \mathrm{Cl}]_{2} /$ optically active phosphine $\mathrm{L} ; \mathrm{Rh}$ : substrate ratio $=1: 50$; reaction temperature $0 \rightarrow 20^{\circ} \mathrm{C}^{11}$, 12); work-up method $\mathrm{A}$

\begin{tabular}{|c|c|c|c|c|c|c|c|}
\hline $\begin{array}{l}\text { substrate } \\
\text { imine }\end{array}$ & $\begin{array}{c}\text { phosphine } \\
\text { L }\end{array}$ & $\mathrm{Rh} / \mathrm{L}$ & $\begin{array}{c}\mathrm{t} \\
(\mathrm{h})\end{array}$ & $\begin{array}{l}\text { number } \\
\text { of runs }\end{array}$ & $\begin{array}{l}\text { isolated } \\
\text { product }\end{array}$ & $\begin{array}{l}\text { chemical } \\
\text { yield }(\%)\end{array}$ & $\begin{array}{c}\text { optical induction } \\
\text { ee }(\%)\end{array}$ \\
\hline $1 \mathrm{a}$ & (+)-Diop & $1: 1.8$ & 48 & 1 & $3 a^{3)}$ & 90 & 64.5 \\
\hline $1 \mathrm{a}$ & (-)-Diop & $1: 1.8$ & 48 & 4 & $4 a$ & 90 & $62.5-65.1(\mathrm{R})$ \\
\hline $1 a^{1)}$ & (-)-Diop & $1: 1.8$ & 48 & 1 & $4 a$ & 87 & $\begin{array}{ll}39.4 & \text { (R) }\end{array}$ \\
\hline $1 a^{2)}$ & (-)-Diop & $1: 1.8$ & 48 & 2 & $4 a$ & 88 & $39.1-40.9$ (R) \\
\hline $1 \mathrm{a}$ & (+)-Prophos & $1: 1.2$ & 40 & 3 & $4 a$ & 88 & $27.4-28.2(\mathrm{~S})$ \\
\hline $1 \mathrm{a}$ & $(+)$-BPPFA & $1: 1.2$ & 40 & 3 & $4 a$ & 92 & $11.6-12.7(\mathrm{~S})$ \\
\hline $1 \mathrm{a}$ & (-)-Norphos & $1: 1.3$ & 40 & 2 & $4 a$ & 90 & $21.9-22.9(\mathrm{R})$ \\
\hline $1 b$ & $(-)-$ Diop & $1: 1.8$ & 48 & 3 & $4 b$ & 92 & $36.8-37.9(\mathrm{R})$ \\
\hline $1 \mathrm{c}$ & (-)-Diop & $1: 1.8$ & 48 & 3 & $4 c$ & 91 & $49.1-50.5(\mathrm{R})$ \\
\hline 5 & $(+)$-Diop & $1: 1.8$ & 48 & 6 & 7 & 28 & $61.5-66.1(\mathrm{~S})$ \\
\hline 5 & $(+)$-Diop & $1: 1.8$ & $\begin{array}{l}40 \\
48\end{array}$ & 1 & $8^{3)}$ & 32 & $63.3 \quad$ (S) \\
\hline $10^{4)}$ & (+)-Diop & $\begin{array}{l}1.1 .0 \\
1: 1.3\end{array}$ & $\begin{array}{l}40 \\
48\end{array}$ & $\begin{array}{l}1 \\
1\end{array}$ & $12^{3)}$ & 90 & 33.0 \\
\hline
\end{tabular}

1) Solvent $2 \mathrm{ml} \mathrm{CH}_{2} \mathrm{Cl}_{2}$.

2) Solvent $2 \mathrm{ml} \mathrm{CHCl} 3$.
3) Work-up method B.

4) $0.4 \mathrm{mmol} 10,1 \mathrm{mmol} \mathrm{H}_{2} \mathrm{SiPh}_{2} ; \mathrm{Rh}$ : substrate ratio = 1:10. group can also be removed from the $\mathrm{N}$-atom, nornicotine can be synthesized from the corresponding $\mathrm{N}$-formyl derivative ${ }^{6}$.

The tobacco alkaloid nicotine 9 was prepared by hydrosilylation of the natural product myosmine $5^{6}$ to give 6 , workup with acetic formic anhydride and reduction of 8 with $\mathrm{HCHO} / \mathrm{HCOOH}$ (Scheme 2).

After hydrosilylation of 5 with $\left[\mathrm{Rh}(\operatorname{cod}) \mathrm{Cl}_{2} /(+)\right.$-Diop, the $\mathrm{N}$-silylamine 6 was treated with trifluoroacetic anhydride to give $\mathbf{7}$ als well as with acetic formic anhydride to give 8. 7 was shown to have an enantiomeric excess of $63.3 \%$ (S). As 8 could not be measured by GC, it was reduced with $\mathrm{HCHO} /$ $\mathrm{HCOOH}$ to nicotine 9 , which according to polarimetric measurements in $1 \%$ aqueous $\mathrm{KOH}^{9)}$ had an optical purity of $63.3 \%(\mathrm{~S})$.

The hydrosilylation of the Preininger Alkaloid 10, which is insoluble in toluene, was carried out in methylene chloride with the catalyst $\left[\mathrm{Rh}(\operatorname{cod}) \mathrm{Cl}_{2} /(+)\right.$-Diop. After $72 \mathrm{~h}$ the hydrosilylation was complete. Treatment of 11 with acetic formic anhydride gave 12 which was reduced to 13 . The enantiomeric excess, determined by optical rotation, was $33 \%$ $(\mathrm{S})^{10)}$.

The enamides 14 and 15 were prepared in yields $>90 \%$ by treating the cyclic imine 1a with acetic formic anhydride or trifluoroacetic anhydride, respectively (Scheme 4).

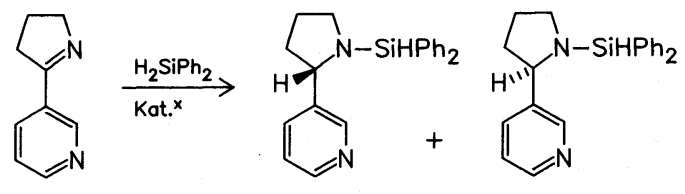

5<smiles>COC(=O)OC</smiles>

6

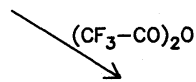

$\overbrace{-\mathrm{N}}^{\mathrm{N}-\mathrm{CH}=\mathrm{O}}$<smiles>O=CN1CCC[C@H]1c1cccnc1</smiles>
$\mathrm{H}_{2} \mathrm{CO} / \mathrm{H}-\mathrm{COOH}$<smiles>O=C(OC(F)(F)F)N1CCCC1(c1cccnc1)N(OC(F)(F)F)C(F)(F)F</smiles><smiles>CN1CCC[C@H]1c1cccnc1</smiles>

The hydrogenations of $\mathbf{1 4}$ and $\mathbf{1 5}$ were carried out in a 100 $\mathrm{ml}$ autoclave (Table 2). The chiral phosphine ligands (+)Prophos, (-)-Norphos, (+)-BPPFA and (-)-Diop in the rhodium catalyzed hydrogenation of $\mathbf{1 5}$ gave optical inductions decreasing from $36.1 \%$ ee (Table 2 ). The preferred configuration is (R) except for (-)-Diop which gives predominantly (S)-products.<smiles>COc1cc2c(Cc3ccc4c(c3)OCO4)nc(C3=NCCC3)c(CC3CCC3)c2cc1OC</smiles>

Preininger Alkaloid (10)<smiles></smiles>

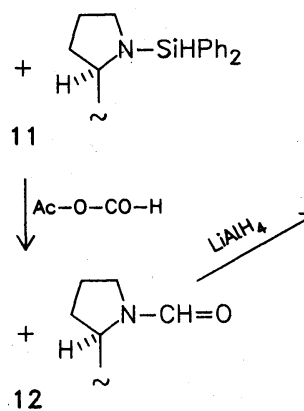<smiles>COc1cc2c(cc1OC)[C@H](c1ccc(Cc3ccc4c(c3)OCO4)nc1)N(C)CCC2</smiles>

(S)-(-)-Macrostomine<smiles>COc1cc2c([C@@H]3CCCN3C)cnc(Cc3ccc4c(c3)OCO4)c2cc1OC</smiles>

(both as rotamers) 


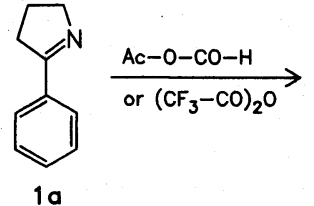

Scheme 4
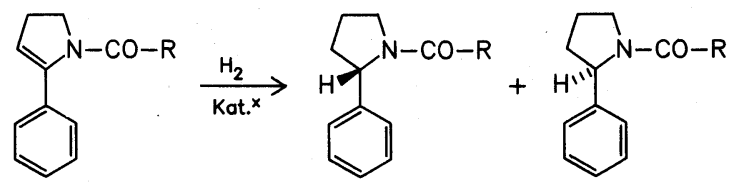

14: $\mathrm{R}=\mathrm{H}$

15: $\mathrm{R}=\mathrm{CF}_{3}$

3a: $R=H$

4a: $R=C F_{3}$

In an attempt to prepare the alkaloid macrostomine 13 by enantioselective hydrogenation of the enamine, derived from 10 by formally replacing the 3,4-dihydropyrrole system by the $\mathrm{N}$-methyl-4,5-dihydropyrrole moiety ${ }^{6}$, with the catalyst $\left[\mathrm{Rh}(\operatorname{cod}) \mathrm{Cl}_{2} /(-)\right.$-Norphos, there was no reaction even at $\mathrm{H}_{2^{-}}$ pressures of up to 65 bar.

\section{Experimental Part}

\section{General remarks}

IR-spectra: Beckman Acculab 3. - ${ }^{1} \mathrm{H}-\mathrm{NMR}$ spectra: Varian EM $390(90$ $\mathrm{MHz})$, Bruker WM $250(250 \mathrm{MHz})$ und Varian EM $360 \mathrm{~L}(60 \mathrm{MHz})$; $35^{\circ} \mathrm{C}$, i-TMS in $\mathrm{CDCl}_{3}$. - MS: Varian MAT CH 5. - Optical rotation: Perkin-Elmer polarimeter 24 1. - GC: Varian Aerograph 1800, T(injector) $250^{\circ} \mathrm{C}, 50 \mathrm{~m}$-Chirasil-L-Val column, FID; integrator: Spectra Physics SP 4100.

Hydrosilylation and hydrogenation reactions were carried out in dry solvents with exclusion of air.

\section{Hydrosilylation}

Method A: The procatalyst $[\mathrm{Rh}(\operatorname{cod}) \mathrm{Cl}]_{2}(10 \mathrm{mg}, 0.040 \mathrm{mmol} \mathrm{Rh})$, the optically active cocatalyst $(0.048 \mathrm{mmol})$, and the imine $(2 \mathrm{mmol})$ were dissolved in toluene $(2 \mathrm{ml})$. The solution was stirred for $10 \mathrm{~min}$ at room temp. and then cooled to $0^{\circ} \mathrm{C}$. After $10 \mathrm{~min}$ diphenylsilane $(0.92 \mathrm{ml}, 5 \mathrm{mmol})$ was added. Then, the reaction mixture was slowly warmed up to room temp. and stirred for the reaction time indicated in Table 1. For work-up, the solution was cooled to $0^{\circ} \mathrm{C}$, THF $(2 \mathrm{ml})$ and an excess of trifluoroacetic anhydride $(0.8 \mathrm{ml})$ was added. The mixture was stirred for $10 \mathrm{~min}$ at room temp. and cooled to $0{ }^{\circ} \mathrm{C}$. Addition of a saturated $\mathrm{NaHCO}_{3}$ solution $(8 \mathrm{ml})$ brought the $\mathrm{pH}$ to $8-9$. The mixture was extracted three times with $15 \mathrm{ml}$ of ether. The ether layers were dried over $\mathrm{MgSO}_{4}$.
After filtration the solvent was removed and the product was purified by Kugelrohr distillation.

For the determination of the enantiomeric excess, about $30 \mathrm{mg}$ of the trifluoroacetamide were dissolved in $1 \mathrm{ml}$ of $\mathrm{CH}_{2} \mathrm{Cl}_{2}$. This solution was used for the GC analysis the conditions of which are given for each individual compound.

Method B: Acetic formic anhydride ${ }^{15)}$ was used for work-up instead of trifluoroacetic anhydride. The resulting formamide was analyzed in the same way as the trifluoroacetamide.

\section{Hydrogenation}

The procatalyst $\left[\mathrm{Rh}(\operatorname{cod}) \mathrm{Cl}_{2}(10 \mathrm{mg}, 0.040 \mathrm{mmol} \mathrm{Rh})\right.$, the cocatalyst $(0.073 \mathrm{mmol})$, and the enamine $(1.0 \mathrm{mmol})$ were dissolved in $\mathrm{MeOH}(5$ $\mathrm{ml}$ ). The solution was stirred in a $100 \mathrm{ml}$ autoclave at $20 \mathrm{bar} \mathrm{H}_{2}$ pressure. After the reaction time indicated in Table 2 the solvent was removed and the product was purified by Kugelrohr distillation.

About $20 \mathrm{mg}$ of the pure product were dissolved in $1 \mathrm{ml}$ of $\mathrm{CH}_{2} \mathrm{Cl}_{2}$ for measuring the enantiomeric excess by GC as described for each compound.

\section{(S)-(-)-N-Formyl-2-phenylpyrrolidine (3a)}

Obtained by hydrosilylation of $1 \mathrm{a}^{3)}$ (method B). B. p. $120^{\circ} \mathrm{C} / 0.05 \mathrm{~mm}$ $\mathrm{Hg}$, colourless oil. Yield $95 \%$. - IR (film): NCO $1671 \mathrm{~cm}^{-1}$. - ${ }^{1} \mathrm{H}-\mathrm{NMR}$ (mixture of rotamers): $\delta(\mathrm{ppm})=1.68-2.58(\mathrm{~m}, 4 \mathrm{H}), 3.50-3.85(\mathrm{~m}, 2 \mathrm{H})$, $4.74-4.95(\mathrm{~m}, 0.75 \mathrm{H}), 4.95-5.22(\mathrm{~m}, 0.25 \mathrm{H}), 7.30-7.53(\mathrm{~m}, 5 \mathrm{H}), 8.10(\mathrm{~s}$, $0.75 \mathrm{H}), 8.30(\mathrm{~s}, 0.25 \mathrm{H})$. - GC-determination of ee (Table 1): T(column) $\left(\mathrm{T}_{\mathrm{c}}\right) 115^{\circ} \mathrm{C}$, retention time (r. t.) 91.5 and $93.0 \mathrm{~min}$.

\section{(R)-(+)-N-Trifluoroacetyl-2-(3-methylphenyl)pyrrolidine (4b)}

By hydrosilylation of $1 \mathbf{b}^{16)}(\operatorname{method} A)$. B. p. $120^{\circ} \mathrm{C} / 0.05 \mathrm{~mm} \mathrm{Hg}$, colourless oil. Yield $>90 \%$. - IR (film): NCO $1695 \mathrm{~cm}^{-1}$. - $60 \mathrm{MHz}^{-1} \mathrm{H}-\mathrm{NMR}$ : $\delta(\mathrm{ppm})=1.70-2.33(\mathrm{~m}, 4 \mathrm{H}), 2.37(\mathrm{~s}, 3 \mathrm{H}), 3.67-4.03(\mathrm{~m}, 2 \mathrm{H}), 5.05-5.38$ $(\mathrm{m}, 1 \mathrm{H}), 6.80-7.60(\mathrm{~m}, 4 \mathrm{H})$. - GC-determination of ee (Table 1): $\mathrm{T}_{\mathrm{c}}$ $135^{\circ} \mathrm{C}$, r. t. 34.0 and $35.0 \mathrm{~min}$.

\section{(R)-(+)-N-Trifluoroacetyl-2-(4-methylphenyl)pyrrolidine (4c)}

By hydrosilylation of $1 \mathrm{c}^{16)}(\operatorname{method} \mathrm{A})$. B. p. $120^{\circ} \mathrm{C} / 0.05 \mathrm{~mm} \mathrm{Hg}$, colourless oil. Yield > $90 \%$. - IR (film): NCO $1694 \mathrm{~cm}^{-1}$. - ${ }^{1} \mathrm{H}-\mathrm{NMR}$ : $\delta$ (ppm) $=1.67-2.47(\mathrm{~m}, 4 \mathrm{H}), 2.33(\mathrm{~s}, 3 \mathrm{H}), 3.63-4.03(\mathrm{~m}, 2 \mathrm{H}), 5.03-5.42(\mathrm{~m}, 1 \mathrm{H})$, 6.85-7.80 (m, 4H). - GC-determination of ee (Table 1): $\mathrm{T}_{\mathrm{c}} 135^{\circ} \mathrm{C}$, r. t. 34.2 and $35.2 \mathrm{~min}$.

\section{(S)-(-)-N-Trifluoroacetyl-2-(3-pyridinyl)pyrrolidine (7)}

By hydrosilylation of $5^{17)}$ (method A). After drying $\left(\mathrm{MgSO}_{4}\right)$ the residue was purified by column chromatography $(\mathrm{cc})\left(\mathrm{SiO}_{2}\right.$, Merck; ethyl aceta-

Table 2. Hydrogenation of $1 \mathrm{mmol}$ of enamine $14,15 \mathrm{in} 5 \mathrm{ml} \mathrm{MeOH}$ with the in-situ catalysts [ $\mathrm{Rh}(\operatorname{cod}) \mathrm{Cl}]_{2} /$ optically active phosphine $\mathrm{L}$ at $20^{\circ} \mathrm{C}$ and 20 bar $\mathrm{H}_{2}$-pressure $\left.{ }^{13}, 14\right)$

$\mathrm{Rh} /$ substrate $=1: 25 ; \mathrm{Rh} / \mathrm{L}=1: 1.8$.

\begin{tabular}{|c|c|c|c|c|c|c|}
\hline $\begin{array}{l}\text { substrate } \\
\text { enamine }\end{array}$ & $\begin{array}{c}\text { phosphine } \\
\text { L }\end{array}$ & $\begin{array}{c}\mathrm{t} \\
(\mathrm{h})\end{array}$ & $\begin{array}{l}\text { number } \\
\text { of runs }\end{array}$ & $\begin{array}{l}\text { isolated } \\
\text { product }\end{array}$ & $\begin{array}{l}\text { chemical } \\
\text { yield }(\%)\end{array}$ & $\begin{array}{c}\text { optical induction } \\
\text { ee (\%) }\end{array}$ \\
\hline $14^{1)}$ & (-)-Norphos & 120 & 1 & $3 \mathbf{a}$ & 45 & $10.7 \quad(R)$ \\
\hline 15 & (-)-Norphos & 72 & 2 & $4 a$ & 91 & $27.5-28.0(\mathrm{R})$ \\
\hline 15 & (+)-BPPFA & 90 & 3 & $4 a$ & 54 & $17.4-19.6(\mathrm{R})$ \\
\hline 15 & (-)-Diop & 72 & 3 & $4 a$ & 94 & $9.4-10.5(\mathrm{~S})$ \\
\hline
\end{tabular}

$\begin{array}{ll}\text { 1) } \mathrm{Rh} / \text { substrate }=1: 10 . & \text { 2) Solvent } 5 \mathrm{ml} \text { toluene. }\end{array}$

3) Solvent $5 \mathrm{ml} \mathrm{THF}$. 
te), followed by Kugelrohr distillation $\left(100-110^{\circ} \mathrm{C}, 0.1 \mathrm{~mm} \mathrm{Hg}\right)$. Colourless oil. Yield $28 \%$. - IR (film): NCO $1700 \mathrm{~cm}^{-1}$. - ${ }^{1} \mathrm{H}-\mathrm{NMR}: \delta(\mathrm{ppm})=$ $1.77-2.65(\mathrm{~m}, 4 \mathrm{H}), 3.65-4.12(\mathrm{~m}, 2 \mathrm{H}), 5.10-5.45(\mathrm{~m}, 1 \mathrm{H}), 7.15-7.60(\mathrm{~m}$, $2 \mathrm{H}), 8.40-8.68(\mathrm{~m}, 2 \mathrm{H}) .-\mathrm{MS}(70 \mathrm{eV}): \mathrm{m} / \mathrm{z}=244\left(\mathrm{M}^{+\cdot}, 23 \%\right), 175(60)$, $166(41), 147(100)$. - GC-determination of ee (Table 1): $T_{c} 140^{\circ} \mathrm{C}$, r. t. 24.0 and $25.1 \mathrm{~min}$.

\section{(S)-(-)-N-Formyl-2-(3-pyridinyl)pyrrolidine, I(S)-(-)-N-Formylnornico tine/ (8)}

By hydrosilylation of $5^{17}$ (method B). Work-up included cc-purification as described for 7. Colourless oil. Yield $32 \%$. IR (film): NCO $1670 \mathrm{~cm}^{-1}$. ${ }^{1} \mathrm{H}-\mathrm{NMR}^{6)}$ (mixture of rotamers): $\delta(\mathrm{ppm})=1.75-2.15(\mathrm{~m}, 3 \mathrm{H})$, 2.25-2.60 (m, 1H), 3.47-3.97 (m, 2H), 4.85-5.20 (m, 1H), 7.27-7.54 (m, $2 \mathrm{H}), 8.39(\mathrm{~s}, 0.35 \mathrm{H}), 8.15(\mathrm{~s}, 0.65 \mathrm{H}), 8.67-8.40(\mathrm{~m}, 2 \mathrm{H})$.

\section{(S)-(-)-Nicotine (9)}

$26.4 \mathrm{mg} 8$ were heated to $100^{\circ} \mathrm{C}$ in an autoclave with $1 \mathrm{ml} \mathrm{HCHO}(37 \%)$ and $1 \mathrm{ml} \mathrm{HCOOH}(98 \%)$. After $18 \mathrm{~h}$ the autoclave was cooled to $0^{\circ} \mathrm{C}$. The excess of $\mathrm{HCOOH}$ and $\mathrm{HCHO}$ was removed, the residue was treated with $2 \mathrm{~N} \mathrm{NaOH}$ and extracted with $\mathrm{CH}_{2} \mathrm{Cl}_{2}$ after saturation with $\mathrm{NaCl}$. After drying $\left(\mathrm{Na}_{2} \mathrm{SO}_{4}\right)$ the solvent was removed and the crude product was purified by careful Kugelrohr distillation with efficient cooling (dry ice) at $35-40^{\circ} \mathrm{C} / 0.1 \mathrm{~mm} \mathrm{Hg}$. Colourless oil. Yield $90 \%$. - IR (film): $\mathrm{NCH}_{3} 2793 \mathrm{~cm}^{-1}$. - ${ }^{1} \mathrm{H}-\mathrm{NMR}: \delta(\mathrm{ppm})=1.50-2.52(\mathrm{~m}, 5 \mathrm{H}), 2.11(\mathrm{~s}, 3 \mathrm{H})$, 2.92-3.44 (m, 2H), 7.12-7.37 (m, 1H), 7.59-7.80 (m, 1H), 8.38-8.63 (m, $2 \mathrm{H}) .-[\alpha]_{\mathrm{D}}^{24}=-49.23^{\circ}\left(\mathrm{c} 0.9 ; 1 \% \mathrm{KOH}^{9)}\right)$, corresponding to $63.3 \%$ ee (S).

(S)-(-)-6,7-Dimethoxy-1-(3,4-methylenedioxybenzyl)-4-(N-formylpyrrolidinyl-2-)isoquinoline, I $\mathrm{N}$-Formylnormacrostomine/ (12)

By hydrosilylation of $\mathbf{1 0}^{10)}$ (method $\mathrm{B}$ ) with $\mathrm{Rh}$ :substrate ratio 1:10 and $\mathrm{CH}_{2} \mathrm{Cl}_{2}$ as solvent. Work-up: $2 \mathrm{ml}$ of acetic formic anhydride were added to the solution at $0^{\circ} \mathrm{C}$. After $20 \mathrm{~min}$ the excess of anhydride was destroyed with a saturated $\mathrm{NaHCO}_{3}$-solution $(8 \mathrm{ml})$ and the mixture was extracted immediately with $\mathrm{CH}_{2} \mathrm{Cl}_{2}$. After drying $\left(\mathrm{Na}_{2} \mathrm{SO}_{4}\right)$ and cc (neutral alumina, activity grade 2, Woelm; $\mathrm{CHCl}_{3}$ ) a pale oil was obtained. Yield $81 \%$. ${ }^{1} \mathrm{H}-\mathrm{NMR}$ (crude; mixture of rotamers): $\delta(\mathrm{ppm})=1.81-2.26(\mathrm{~m}, 4 \mathrm{H})$, 3.63-4.22 (m, 2H), $3.91(\mathrm{~s}, 3 \mathrm{H}), 4.01(\mathrm{~s}, 3 \mathrm{H}), 4.49(\mathrm{~s}, 2 \mathrm{H}), 5.34-5.57(\mathrm{~m}$, $0.8 \mathrm{H}), 5.69-5.81(\mathrm{~m}, 0.2 \mathrm{H}), 5.87(\mathrm{~s}, 2 \mathrm{H}), 6.73(\mathrm{~s}, 3 \mathrm{H}), 6.99-7.47(\mathrm{~m}, 2 \mathrm{H})$, $8.03-8.30(\mathrm{~m}, 1.6 \mathrm{H}), 8.46(\mathrm{~s}, 0.4 \mathrm{H})$. - IR- and mass spectra were measured using the white amorphous powder obtained on trituration of $5 \mathrm{mg}$ of crude 12 with a few drops of butyl methyl ether. - IR (KBr): NCO 1673 $\mathrm{cm}^{-1}$. - MS (70 eV): $\mathrm{m} / \mathrm{z}=420\left(\mathrm{M}^{+\cdot}, 94 \%\right), 419(100), 405$ (58), 391 (17), 389 (23), 377 (11), 310 (19).

\section{Reduction of 12 to (S)-(-)-Macrostomine (13)}

To a suspension of $\mathrm{LiAlH}_{4}(31 \mathrm{mg})$ in $4 \mathrm{ml}$ of absol. THF was added 12 $\left(22 \mathrm{mg}\right.$ ) in $3 \mathrm{ml}$ of absol. THF dropwise at $0^{\circ} \mathrm{C}$ under $\mathrm{N}_{2}$ protection. After stirring $15 \mathrm{~min}$ at $0^{\circ} \mathrm{C}$ and $15 \mathrm{~min}$ at room temp. the suspension was refluxed for $40 \mathrm{~min}$. Curiously the reduction is accompanied by formation of a deep red color as already stated in ref. ${ }^{18}$ ). After cooling to $0^{\circ} \mathrm{C}$ the excess of $\mathrm{LiAlH}_{4}$ was destroyed by a few drops of water, the precipitate was stirred subsequently $3 \mathrm{x}$ with $10 \mathrm{ml}$ of ether and $1 \mathrm{x}$ with $10 \mathrm{ml}$ of $\mathrm{CH}_{2} \mathrm{Cl}_{2}$. After drying the combined filtrate and extracts $\left(\mathrm{Na}_{2} \mathrm{SO}_{4}\right)$, the solvent was evaporated, giving $26 \mathrm{mg}$ of crude 13 (macrostomine). $\mathrm{Cc}(4 \mathrm{~cm}, 1.5 \mathrm{~cm}$ $\varnothing$, neutral alumina, act. grade 2, Woelm; $\mathrm{CH}_{2} \mathrm{Cl}_{2} / \mathrm{CH}_{3} \mathrm{CN}$ 9:1) afforded $19.3 \mathrm{mg}(90 \%)$ of amorphous 13 ; [a $]_{\mathrm{D}}^{25}-17.4^{\circ}\left(\mathrm{c} 0.89, \mathrm{CHCl}_{3}\right)$, corresponding to $33 \%$ ee (S) ${ }^{10)}$ - $250 \mathrm{MHz}-{ }^{1} \mathrm{H}-\mathrm{NMR}$ : $\delta(\mathrm{ppm})=1.81-2.15$ $(\mathrm{m}, 3 \mathrm{H}), 2.25(\mathrm{~s}, 3 \mathrm{H}), 2.18-2.46(\mathrm{~m}, 2 \mathrm{H}), 3.26-3.38(\mathrm{~m}, 1 \mathrm{H}), 3.48-3.62$ $(\mathrm{m}, 1 \mathrm{H}), 3.89(\mathrm{~s}, 3 \mathrm{H}), 4.02(\mathrm{~s}, 3 \mathrm{H}), 4.48(\mathrm{~s}, 2 \mathrm{H}), 5.87(\mathrm{~s}, 2 \mathrm{H}), 6.68-6.82$ (m, 3H), 7.32 (s, 1H), 7.80 (s, 1H), 8.40 (s, 1H). - IR-, UV-, ${ }^{1} \mathrm{H}-\mathrm{NMR}$ $(90 \mathrm{MHz})$ and mass spectra as well as tlc in 16 solvents were identical with those of an authentic sample of macrostomine racemate ${ }^{19}$.

\section{$N$-Formyl-4,5-dihydro-2-phenylpyrrole (14)}

$580.08 \mathrm{mg}(4 \mathrm{mmol})$ of $1 \mathrm{a}^{3}$ ), dissolved in $5 \mathrm{ml}$ of acetic formic anhydride, were stirred $15 \mathrm{~min}$ at $0^{\circ} \mathrm{C}$, then $1 \mathrm{~h}$ at room temp. The excess of anhydride was distilled off i. vac. at $30^{\circ} \mathrm{C}$. Kugelrohr distillation $\left(100-105^{\circ} \mathrm{C} /\right.$ $0.05 \mathrm{~mm} \mathrm{Hg}$ ) of the residue gave a colourless oil. Yield $669 \mathrm{mg}(95 \%) .14$ is stable under $\mathrm{N}_{2}$ at $-20^{\circ} \mathrm{C}$ for at least 3 weeks. - IR (film): NCO 1670 $\mathrm{cm}^{-1}$. - ${ }^{1} \mathrm{H}-\mathrm{NMR}: \delta(\mathrm{ppm})=2.54-2.86(\mathrm{~m}, 2 \mathrm{H}), 3.86-4.20(\mathrm{~m}, 2 \mathrm{H})$, 5.19-5.35 (m, 1H), 7.18-7.58 (m, 5H), $8.40(\mathrm{~s}, 1 \mathrm{H})$.

Enantioselective hydrogenation of $\mathbf{1 4}$ gave $\mathbf{3 a}$ (see above) (Table 2).

\section{N-Trifluoroacetyl-4,5-dihydro-2-phenylpyrrole (15)}

To $2.904 \mathrm{~g}(0.02 \mathrm{~mol})$ of $1 \mathrm{a}^{3)}$ in $10 \mathrm{ml}$ of absol. THF were added drop by drop $3.5 \mathrm{ml}$ of $\left(\mathrm{F}_{3} \mathrm{C}-\mathrm{CO}\right)_{2} \mathrm{O}$ in $5 \mathrm{ml}$ of absol. THF ab $0{ }^{\circ} \mathrm{C}$. This solution was stirred for $30 \mathrm{~min}$ at $0^{\circ} \mathrm{C}$, then $30 \mathrm{~min}$ at room temp. The excess of THF and of the anhydride was removed i. vac. at $10^{\circ} \mathrm{C} / 0.05 \mathrm{~mm} \mathrm{Hg}$, the residue was distilled by $\mathrm{Kugelrohr}$ distillation $\left(70^{\circ} \mathrm{C} / 0.05 \mathrm{~mm} \mathrm{Hg}\right)$ : colourless oil, which gave white crystals on standing. Yield $4.34 \mathrm{~g}(90 \%)$. Recrystallization from hexane, m.p. $46-47^{\circ} \mathrm{C} .15$ is stable under $\mathrm{N}_{2}$ at $-20^{\circ} \mathrm{C}$ at least for 1 month. $\mathrm{C}_{12} \mathrm{H}_{10} \mathrm{~F}_{3} \mathrm{NO}(241.2)$ Calc. $\mathrm{C} 59.8 \mathrm{H} 4.18$ N 5.8 Found C $59.8 \mathrm{H} 4.19 \mathrm{~N} \mathrm{5.7.} \mathrm{-} \mathrm{IR} \mathrm{(KBr):} \mathrm{NCO} 1700 \mathrm{~cm}^{-1}$. $-{ }^{1} \mathrm{H}$ NMR: $\delta(p p m)=2.53-2.85(\mathrm{~m}, 2 \mathrm{H}), 4.15-4.30(\mathrm{~m}, 2 \mathrm{H}), 5.70-5.80(\mathrm{~m}$, $1 \mathrm{H}), 7.13-7.40(\mathrm{~m}, 5 \mathrm{H})$.

Enantioselective hydrogenation of $\mathbf{1 5}$ gave $\mathbf{4 a}$ (see above) (Table 2).

\section{References}

1 Asymmetric Catalysis, part 38. For part 37 see $\mathrm{H}$. Brunner and $\mathrm{H}$. Fisch, J. Organomet. Chem., 335, 15 (1987).

2 H. B. Kagan, N. Langlois, and T. P. Dang, J. Organomet. Chem. 90, 353 (1975).

3 H. Brunner, R. Becker, S. Mahboobi, and W. Wiegrebe, Angew. Chem. 97, 969 (1985); Angew. Chem., Int. Ed. Engl. 24, 995 (1985).

4 R. Noyori, M. Ohta, Yi Hsiao, and M. Kitamura, J. Am. Chem. Soc. 108, 7117 (1986).

5 A. Kürzinger, Ph. D. thesis, University of Regensburg, 1987.

6 S. Mahboobi, Ph. D. thesis, University of Regensburg, 1988.

7 H. Frank, G. J. Nichólson, and E. Bayer, J. Chromatogr. 146, 197 (1978).

8 C. R. Hutchinson and M. Nakane, J. Org. Chem. 43, 3922 (1978).

9 E. Späth, C. S. Hicks, and E. Zajie, Ber. Dtsch. Chem. Ges. 68,1388 (1935).

10 V. A. Mnatsakanyan, V. Preininger, V. Šimánek, J. Juřina, A. Klásek, L. Dolejs, and F. Šantavý, Collect. Czech. Chem. Commun. 42, 1421 (1977). This alkaloid (no. IV in that publication) is not an enamine, but an imine: S. Mahboobi and W. Wiegrebe, Sci. Pharm. (Vienna) 54, 217 (1986).

11 H. Brunner and G. Riepl, Angew. Chem. 94, 369 (1982); Angew. Chem., Int. Ed. Engl. 21, 377 (1982); Angew. Chem. Suppl. 769 (1982).

12 H. Brunner, B. Reiter, and G. Riepl, Chem. Ber. 117, 1330 (1984).

13 H. Brunner and W. Pieronczyk, J. Chem. Res. (S), 76 (1980); (M), 1275 (1980).

14 H. Brunner, W. Pieronczyk, B. Schönhammer, K. Streng, I. Bernal, and J. Korp, Chem. Ber. 114, 1137 (1981).

15 L. F. Fieser and M. Fieser, Reagents for Organic Synthesis, p. 4, J. Wiley and Sons, Inc., New York 1967.

16 Prepared analogously to $1 \mathrm{a}$, c. f. lit. 6 .

17 E. Leete, M. R. Chedekel, and G. B. Bodem, J. Org. Chem. 37, 4465 (1972).

18 W. Wykypiel, Dissertation, ETH Zürich (Chem.), Nr. 6682, p. 144.

19 W. Wiegrebe, S. Mahboobi, G. Dannhardt, K. K. Mayer, and E. Eibler, Chimia 35, 288 (1981).

$[\mathrm{Ph} \mathrm{357]}$ 